\title{
Varroa destructor AND A THREAT OF VIRAL INFECTIONS OF THE HONEYBEE (Apis mellifera L.)
} (review)

\section{A.V. SPRYGIN ${ }^{1}$, Yu.Yu. BABIN ${ }^{1}$, E.M. KHANBEKOVA ${ }^{2}$, L.E. RUBTSOVA ${ }^{2}$}

\author{
${ }^{1}$ Federal Center for Animal Health Control, FGBU VNIIZZh, mkr. Yurievets, Vladimir, 600901 Russia, e-mail \\ sprygin@arriah.ru; \\ ${ }^{2}$ Institute of Zoology, Azerbaijan National Academy of Sciences, block 504, passage 1128, A. Abasov str., Baku AZ \\ 1.1073, Azerbaijan Republic, e-mail golden_hive@hotmail.com \\ Received August 31, 2015
}

\section{Abstract}

Bee viral infections worldwide leading to colonies' depopulation have emerged as a threat to bee keeping. To date, nearly 20 RNA viruses, of Dicistroviridae, Iflaviridae, Nodaviridae families mostly, were detected in honeybee Apis mellifera (O.F. Grobov et al., 2006; C. Runckel et al., 2011). Also DNA viruses have been found, e.g. iridovirus (Iridoviridae), potentially causing losses of bee colonies (J.J. Bromenshenk et al., 2010), Aphid Lethal Paralysis virus (Dicistroviridae), Big Sioux River virus (Dicistroviridae), Lake Sinai Virus strain 1 and 2 (Nodaviridae) (C. Runckel et al., 2011) however, their role in bee mortality has yet to be understood. The most important bee viruses known to date are deformed wing virus (DWV), acute bee paralysis virus, (ABPV), chronic bee paralysis virus (CBPV), Kashmir bee virus, (KBV), sacbrood virus, (SBV), Black queen cell virus (BQCV). These viruses can persist in honey bees (Apis mellifera L.) without apparent symptoms, however, Varroa destructor infestation causes a viral epidemic, diminishing bee colonies. The range of $V$. destructor, the main viral infections' vector (D. Tentcheva et al., 2004), was confined to that of $A$. cerana being ecologically balanced. However, not long ago this mite crossed the species barrier from the Asian hive bee $A$. cerana to our own Western honey bee $A$. mellifera (R.S. Poltorzhitskaya, 2008). The introduction of $V$. destructor into the $A$. mellifera population has become one of the major contributing factors to colony collapse disorder (D. van Engelsdorp et al., 2008; R.M. Johnson et al., 2009; F. Nazzi et al., 2012). Moreover, the mite Varroa affects the immune response and metabolism of honey bees and allows its vectored viruses to propagate to high viral loads. At present there is an objective need for a closer look into bee viruses implicated in bee colony losses reported worldwide. So far as Varroa mite is an obligate parasite of $A$. mellifera during whole ontogenesis, the Varroa control notably ensures the well-being of bee colonies. In this review, an overview of the world distribution and the impact of the major viruses (DWV, ABPV, CBPV, SBV, BQCV, KBV) on bee health and colony survival is presented. We also discuss approaches to virus control. Overall, the strategy combining new Varroa management practices (A.A. Fedorova et al., 2011), selection of Varroa-resistant bees and novel treatments against viruses will help sustain the honey bee population.

Keywords: Apis mellifera, Varroa destructor, viruses, viral infection transmission, vectors.

To date, nearly 20 RNA viruses, of Dicistroviridae, Iflaviridae, Nodaviridae families mostly, were detected in honeybee Apis mellifera [1-3]. DNA viruses also have been found - iridovirus (Iridoviridae), potentially causing losses of bee colonies [4], Aphid Lethal Paralysis virus (Dicistroviridae), Big Sioux River virus (Dicistroviridae), Lake Sinai Virus strain 1 and 2 (Nodaviridae) [2]. However, their role in bee mortality has yet to be understood.

Active replication of most viruses in insects usually results in negative changes of physiological parameters and behavior up to honeybee colony losses [5-8]. Latent viruses can persist in some individuals or in bee family as a whole and not cause the death [9-11]. Importantly, some viruses when influenced by definite but not clearly understood factors can provoke a decrease in bee cold resistance, queen bee reproductive activity, flying activity of bees and nectar collection [12]. 
Undoubtedly, viral infections are dangerous under bee infestation with Varroa destructor mite, the vector of most harmful viral infection [10]. When biting, an infected mite transmits a causal agent to bee. Varroa mite is an obligate ectoparasite of $A$. mellifera at all stages of ontogenesis. Initially, Asian bee $A$. cerana was the host species, but not long ago this mite crossed the species barrier, and now $A$. mellifera bees are also infected in natural habitats [13, 14].

$A$. cerana and $V$. destructor were ecologically balanced so that the mite did not cause death in the bees. First, the mite can not reproduce in cells with worker $A$. cerana bees $[15,16]$, and the reproduction occurs in drone cells only. Secondly, the $A$. cerana imagoes effectively remove Varroa mites due to active grooming [16]. Thirdly, at high infection load the drone pupas are less viable, not able to break cocoon and dye, and the bees then ignore these cells [17, 18]. Thus about $25 \%$ of mites in the bee colonies are eliminated.

However, lack of defensive behavior in $A$. mellifera, with the exception of less effective grooming, leads to low immunity, a decreased body weight, disorders in water balance and carbohydrate metabolism, and reduced the life expectancy. Finally, bee viability decreases causing colony death or collapse [19-23].

Viral infections in $A$. mellifera were underestimated until Varroa introduction [21]. Nevertheless, high viral infection rate (up to $90 \%$ of bees in some colonies) has been detected by RT-PCR. A combined infection of 5-6 different viruses can be found in highly mite-infested bee colony [29]. A definition of «bee parasitic mite syndrome» is used for symptoms of mite-infested bees with viral pathology [25]. It was shown experimentally that inoculation of virus particles in the bee hemolymph and suppression of the immune response by the Varroa mite reduce the defenses both in a bee and the bee clony, and activate latent viral infections [26].

Of those found to date, the most important bee viruses are deformed wing virus (DWV), acute bee paralysis virus (ABPV), chronic bee paralysis virus (CBPV), Kashmir bee virus (KBV), sacbrood virus (SBV), and black queen cell virus (BQCV).

Deformed wing virus. DWV (Iflaviridae) is found worldwide [27, 28] including Russia [29, 30] and Azerbaijan [31]. DWV is genetically close to Kakugo virus found in aggressive bees in Japan [32, 33]. In Kakugo virus and DWV RNAs are 97-98\% homologous [32]. Currently, A. mellifera is considered the main host species for DWV disseminated due to $V$. destructor [10, 34]. DWV also was detected in $A$. cerana, $A$. florea $[35,36]$ and in bumblebees (Bombus terrestris, B. pascuorum) with deformed wings [3]. DWV was isolated from $V$. destructor [21, 37-39] and Tropilaelaps mercedesae [40, 41], the ectoparasitic mites of honeybees. These are the vectors, especially $V$. destructor which plays important role in DWV transmission [21, 26, 42, 43].

DWV is also detected in Aethina tumida, the small hive beetle providing DWV replication. There are reports of DWV transmission from $A$. mellifera to $A$. tumida [44] and bumblebees [28]. DWV is avirulent in the bees not infested by $V$. destructor. Latent DWVs do not cause clinical symptoms [21, 4547]. DWV can be transmitted transovarially via drone sperm, and between colonies at swarming $[45,48]$.

Characteristic DWV symptoms under high mite infestation are rudimentary and crumpled wings, bloated bellies, and discoloration. These bees are not viable and die 67 hours after they emerged from their cells that leads to weakening bee colonies [25, 49, 50]. Evidence for the $V$. destructor as a vector for DWV has been obtained [21, 51]. In recent experiments it was shown that the presence of viral (-)RNA (the replicative form of DWV genome) in mite causes clinical DWV symptoms in pupas. In the body of a mite from died bee with DWV pa- 
thology the viral particles can reach $10^{10}-10^{12}$ in number. Thus the manifestation of DWV syndrome in bees depends on DWV amplification and accumulation in mites not less then on the virus transmission [43]. When studying DWV location in the mites, the viral particles were found only in the intestinal lumen but no evidence for replication was obtained. Probably, in mite population the DWV is replicatively inactive. For elucidation, the mites must be investigated in the colonies where the bees with deformed wings emerge.

In Europe, depending on the season, up to $100 \%$ of honeybee colonies may be infected with DWV [10, 52]. The presence of DWV together with $V$. destructor in bee colonies before winter period is likely to cause the death in winter time [53-55]. In the absence of mites the DWV infection is symptomless [45], but under the Varroa infestation DWV is activated causing death in honeybees. Before the $V$. destructor attacked Europe in 1970-1980, no manifestation of DWV infection was reported [36]. But nowadays the DWV is considered one of the main reasons for the collapse in the mite-infested bee colonies.

DWV infection is always associated with the presence of $V$. destructor as its vector [22, 37, 51]. In Thailand and France the DWV monitoring has shown that the virus can constantly be present in all mite individuals [10, 56]. The presence of DWV was revealed in $69 \%$ and $90 \%$ of infested bees in Poland and England, respectively [57].

It is statistically proven that bee infestation by $V$. destructor in the summer leads to DWV appearance in the autumn. In 4 year survey of 1,250 honeybee colonies in Germany a relationship was found between winter death rate, Varroa infestation level and the DWV titer in bee body [47, 58, 59].

DWV can also infect wild bees $A$. florea and $A$. dorsata [60]. It is assumed that the DWV and Varroa destructor virus-1 (VDV-1) can cause degeneration of the ovaries in queen bees [61]. When laying DWV infected eggs, the queen bees transmit the virus to offspring causing symptomless carrier state [45, 62]. DWV was detected in faeces of queen bees [63]. Obtained data [64] are in line with another report about DWV detection in the faeces of worker bees [65].

Varroa mite also is a carrier of VDV-1 virus [66], RNA of which is $84 \%$ identical to the RNA of DWV [66, 67]. Moreover, the recombination between VDV-1 and DWV is possible [68], producing recombinant viruses such as VDV$1_{\text {DVD }}$, which are better adapted to the horizontal transfer via mite biting and effectively avoid the immune control of the bee host. They also can replicat to larger loads than DW or VDV-1 that may be indicative of higher virulence of the recombinants for the bees [68].

Acute bee paralysis virus. ABPV is genetically close to KBV and Israeli acute paralysis virus (IAPV) (Dicistroviridae) [69, 70]. ABPV can infect both brood and worker bees. Naturally, ABPV persists in bees without clinical manifestation and does not cause death [8]. Presumably, ABPV can be transmitted via the saliva when feeding larvae and producing beebread. At high infection rate the larvae usually die before sealing, but in case of surviving no clinical manifestation of ABPV occurs in the adults.

ABPV detection in Varroa suggests an involvement in ABPV transmission and dissemination [9, 10, 56]. In addition to acting as a carrier, the mite is able to activate latent infections caused by ABPV. Significant virus accumulation in dead bees with ABPV syndrome and high rate of mite infestation suggests that Varroa can activate the virus replication so that it causes death of the bees [71]. Importantly, an injection of phosphate buffer into bee hemolymph also activate ABPV replication, hence the Varroa mites are not the only agent activating latent ABPV [72]. 
Both ABPV and Varroa mite seem to cause the mass losses of bee colonies in Europe [9, 73]. ABPV is one of two the most common viruses in Austria [52]. For a long time the ABPV was detected in apparently healthy honeybees in Britain [35]. ABPV was found in honeybees in France, Italy, Canada, Chinese, United States [72], and in New Zealand. Currently, ABPV is expanding worldwide due to the $A$. mellifera expansion [35, 36].

Since the $V$. destructor appeared in Europe, the high rate of ABPV infection was detected in the heavily infested bee colonies with dead sealed and unsealed brood. This was first considered in Russia and Germany in the late 1970s and early 1980s [74]. Then similar data were reported from Netherlands, Italy, former Yugoslavia, France [71], Hungary, Austria [52], Denmark [37] and USA [72]. In Germany and Holland in dead honeybees from the colonies of low, medium and high mite infestation the ABPV frequency was $3 \%, 44 \%$ and $80 \%$, respectively.

In France ABPV was found in $58 \%$ of adult bees, and in $23 \%$ of pupas and apparently healthy bees, while the frequency of ABPV-infected Varroa mites was $36 \%$. Viral infection was more frequent in infested colonies in the late summer and autumn that correlated with the peak in Varroa population [10]. In Denmark [75] the ABPV infection was detected in $14 \%$ of bee colonies, in contrast to data obtained in France and Austria for clinically healthy and sick bees (58\% and $68 \%$, respectively) [52]. In the opinion of Danish researchers, these may be due to organic acids used against the mite, which are less effective against varraosis so that bees must withstand higher infestation resulting in higher natural death among ABPV infected bees. In Denmark the ABPV frequency was $73 \%$ in 2004 and $80 \%$ in 2005 [76]. In this investigation the relationship was found between infection, infestation and winter death in the colonies. A reliable dependence of bee winter death on ABPV frequency before hibernation was shown for 2005-2006 season but not for 2004-2005 season. However, the bee death in winter correlates with the rate of bee infestation in both seasons. Reasonably, the latent ABPV can be transmitted and activated by the Varroa mite that is a cause of bee death in winter [76].

Kashmir bee virus and Israeli acute paralysis virus. KBV was first described in 1977 in $A$. cerana [77]. KBV, a RNA virus, when inoculated into the bee hemolymphm, replicates to high titers [78]. Bees infected via hemolymph died within 6 days, but insects which ate KBV preparation remained apparently healthy [78]. Hence, the lethal effect of KBV depends on transmission routes [78, 79]. In these the Varroa mite is of key importance. KBV was first isolated from homogenate of worker bees $A$. mellifera, experimentally infected with extract of $A$. cerana bees from Kashmir (India) [78]. Detection of KBV in $A$. mellifera Australian population is extremely interesting as $A$. cerana, which seems to be the main host bee for KBV, does not inhabit this continent. Then KBV was discovered in $A$. mellifera from Canada and New Zealand [80], on Fiji [81], in USA [49], Europe and Oceania [35, 36, 82]. Currently, KBV is reported in $A$. cerana $[35,77,78], A$. mellifera, bumblebees (B. terrestris, B. pascuorum) and wasps (Vespula germanica). In honeybee populations of North America and New Zealand the KBV infection prevails compared to other viruses [72, 83, 84], though in Europe KBV is rarely found [10, 52, 82, 85].

KBV attacks the bees during whole ontogenesis and usually persists latently in the brood.

IAPV which was isolated in Israel from larvae inoculated with homogenized dead bee, is another dangerous virus closely related to KBV [86]. As its symptoms were similar to those under acute paralysis the virus was called Israeli acute bee paralysis virus (IAPV). The virus is widespread in the Middle East 
KBV and IAPV (Dicistroviridae) are closely related. Together with ABPV they form a common genetic complex with similar transmission routes. Remaining latent in bee larvae, they cause rapid death of adult insects with characteristic clinical symptoms. Genetic analysis of KBV and ABPV revealed about $70 \%$ homology but also some differences [91].

ABPV, KBV and IAPV at low titers can permanently persist in bees without clinical manifestations [72, 89]. When KBV and IAPV titers reach a critical level the infected bees die [77, 86, 88]. An increase in titers in bee hemolymph under natural infection is related to Varroa mite as both vector and activator of virus replication [49, 92, 93].

Research of KBV and IAPV transmission routs [42, 51, 94] showed an important role of $V$. destructor in KBV pathogenicity, but the exact mechanisms of disease development still remained unstudied [42]. It is believed that $V$. destructor suppresses the immune defense in bees, resulting in the activation of resident viruses [19]. In other opinion, the $V$. destructor is a vector, which directly transmits KBV to pupas, as KBV was found in the saliva of the mite [42]. Furthermore, mite infection with KBV and transmission to brood has been proved experimentally [95]. Estimated efficiency of KBV transmission to brood by $V$. destructor amounted to $70 \%$, when the efficiency of mite-to-mite KBV transfer or the rate of infecting mite from brood was $51 \%$. KBV plays a key part in death of the mite-infested bee colonies [72, 77]. Also IAPV virulence is probably due to $V$. destructor. The IAPV presence is a marker of bee colonies collapse in USA. The collapse signs are as follows: there are no dead bees at the bottom of the hive, or next to it, bees left brood and queen, weight of worker bees in the hive critically reduced despite of enough feed [96]. Note, the IAPV is also common in Australia, but there is no collapse of bee colonies. Study of bee collapse in USA [97] and bee death in winter with no signs collapse in Germany [76] revealed a sophisticated relationship in ABPV-KBV-IAPV complex in which $V$. destructor is involved as the activator of latent infection. These three viruses differ in geographic distribution [98], and that is why IAPV or KBV can cause bee death in USA while ABPV has lethal effect in Europe.

IAPV was shown to integrate into bee genome. A fragment of IAPV genome is found in the genome of $30 \%$ of Israel bees [86]. IAPV-specific sequences are also detected in Varroa genome. Moreover, the bees with integrated IAPV genome possess resistance to this virus [86].

Black queen cell virus. BQCV was first isolated from in blackened larvas and pre-pupas from black cells [78]. BQCV affects mainly larvae and pupae queens in sealed cells. Affected larvae are pale-yellow colored and covered with sac-like skin similar to sacbrood. BQCV replication in queen pupas causing blackening and rapid death. Worker bees also can become infected, but with no symptomes. Moreover, when BQCV enters the bee body via alimentary tract it does not replicate.

BQCV is found in North America, Europe, Oceania, Asia, Africa, Midle East ad Azerbaijan [31, 35, 36]. After 5 year studies in Beltsville (MD, USA) the BQCV was shown to be the second of mostly common bee viruses after DWV [27]. In Australia BQCV is the most frequent causal agent leading to queen death during development.

When adults and pupas were compared [10], the BQCV was found in adult bees, preferably in spring and summer.

A relationship occurs between BQCV infection and infestation by microsporidia Nosema apis so that the BQCV frequency in the territory increases as the $N$. apis expands. BQCV replication rate in the presence of $N$. apis infesta- 
tion is much higher.

It is assumed that BQCV is transmitted to the queen via royal jelly from bee-nurse. $N$. apis affects intestine providing BQCV infection. In all parts of England and Wales the worker bees infected by BQCV were co-infected by $\boldsymbol{N}$. apis [8]. In Austria, the $N$. apis was found in $78 \%$ of BQCV-positive samples from apiaries, and in $75 \%$ bee colonies infected by $N$. apis the BQCV was also detected. Similar data were obtained in France [10].

It has been suggested that the Varroa mite can serve as a vector for BQCV. BQCV detection in the mite body on apiaries in Thailand confirms this hypothesis [56], while in other studies [10] the virus in varroa mite has not been found.

Chronic bee paralysis virus. Earlier tracheal mite Acarapis woodi was considered the cause of the bee paralysis, but at the end of the 1960s a viral etiology of adult bee paralysis has been shown with the CBPV as causal agent. Currently CBPV is revealed in worker bees practically worldwide except South America [35, 36]. CBPV at low loads is often found, together with ABPV, in apparently healthy bees. Chronic paralysis virus is less virulent compared to ABPV, so that at CBPV infection it takes several days to cause the death of the bee, whereas at ABPV infection the insect dies for one day.

Under CBPV infection there are usually two types of symptoms. The most pronounced ones are trembling body and wings, crawling along the ground because of the inability to fly, bloated belly and wings kept apart. Other symptoms are loss of hair and a darker appearance. Such individuals are expelled from the hive. Both types of the symptoms can be observed in the same bee colony.

When assessing CBPV infectivity, the virus was injected into the bee hemolymph, applied on the body surface, or added to the feed. It was found that CBPV can easily penetrate through the cuticle in the absence of hair, but in the case of oral infection the virus propagation in the body is minimal and does not lead to death in bees. Tightness in the hive makes the penetration easier. CBPV infection occurs in the presence of two factors. The first factor is bad weather when bees do not fly out of the hive. This explains the higher prevalence of CBPV in France [99]. The second factor is related to used beekeeping technology. Thus, the increase in the area of sunflower crop in France and, as a result, abundant monofloral pollen, led to a rapid decrease in internal hive space that has not been extended timely resulting in the colony death with the typical chronic paralysis symptoms [100]. CBPV is distributed in the world unevenly. In Britain CBPV is very frequent and causes bee colony losses [8], in Austria CBPV is found in $10 \%$ of bee colonies [52], and in France the virus persists in $4 \%$ of bee colonies. Importantly, seasonal dynamics is not characteristic of CBPV [10]. Transcuticular penetration of CBPV is common. In Thailand and France, when the bees and Varroa mites were surveyed to estimate the presence of CBPV, the virus was found in the bees but not in the mites [27]. In another study carried out in France, CBPV was detected in ants (Camponotus vagus and Formica rufa) and in the mite $V$. destructor, with the CBPV replicative RNA form detected in $C$. vagus and $V$. destructor, which proves the latter's role as a CBPV vector. CBPV detection in $C$. vagus suggests the possible transmission by the ants, though with no direct evidence. Ants can be infected by eating infected bees, and bees and ants can also be infected by eating honeydew of green fir aphids Cinara pectinatae. However, to date CBPV has not been found in aphids. Thus, to infect ants, there are still unknown CBPV reservoirs [101].

Sacbrood virus. SBV is widespread in honey bee populations on all continents $[35,36]$. The virus affects the bees at all stages of the life cycle, but the 2-day brood is most affected. Viral infection in adult bees develops without 
clinical manifestations, but shortens the life of individuals. SBV spreads within the hive as the bees, attempting to remove the infected larvae, accumulate the virus in salivary glands and then contaminate food. The food can be used to feed brood or exchanged between individuals. Young larvae are infected by eating infected food. SBV replication begins in larvae and results in its yellowing after sealing brood. With the progression of the disease the cuticle gets tougher and the larva is unable to pupate. The large amounts of virus accumulate under the larval cuticle [1, 102].

Usually the SBV infection is seasonally dependant with domination in spring and summer $[8,10]$. At SBV infection, similar to foulbrood, worker bees usually remove or eat the dead larvae thus promoting further SBV expansion in the hive. In some colonies the hygienic behavior may be less strict, and healthy insects can recognize the latent SBV carriers prior to an increase of viral loads in the mummified bees and manifestation of the symptoms [103].

In numerous publication the mite Varroa involvement in SBV transmission is reported based on identification of the virus in flying bees with high infestation by the mite $[52,73]$, and also in the mites themselves [10, 42, 56].

Prevention of viral diseases in bees. Experimentally, ABPV, BQCV, CBPV, DWV, KBV and SBV are detected in the pollen (BQCV and DWV are also found in honey), ABPV, CBPV, KBV and SBV are present in beebread but absent in the saliva of bees and royal jelly [63]. As to other data, KBV and SBV were reported in royal jelly, honey and pollen [42].

Detection of viruses in $V$. destructor indicates its key role in the transmission of the causal agent in bee colonies [10, 21, 32, 51, 56, 66]. Harmful pathologies due to ABPV, CBPV, slow paralysis virus (SPV), BQCV, KBV, cloudy wing virus (CWV), SBV and DWV, leading to clinical symptoms and death have been recoreded in bee colonies under high level of mite infestation $[10,104]$. Additionally, the rate of virus transmission was shown to depend on mite number in the cell and, consequently, on the total infestation level in the colony. Moreover, in case of uninfected mites in the cell they become infected via hemolymph of infected pupa. Undoubtedly, high mite infestation threatens beekeeping worldwide.

Currently, the development of methods to control mites, bee (A. mellifera) breeding for resistant to the mite, and bee treatment against the viral infections are considered as effective ways. These approaches should be used in combination, as in the metagenomic studies of collapsed and survived bee colonies the $V$. destructor together with IAPV and DWV were proved to be the main markers of the collapse [91].

Varroa abundance must be under control to decrease the losses of honeybee colonies [105]. As the mite activates latent viruses, affects the immunity, and causes metabolic disorders, the Varroa control provides the wellbeing of bee colonies. In the absence of the mite and and favourable conditions viral infections in bees are harmless [106]. Bee viruses are found in drone body [95] and sperm [63, 107], and in queen spermatheca (68), thus indicating vertical rout for virus transmission to offspring and probable infection of queen at mating. Since the bee queen during the life lays tens of thousands of eggs, vertical transmission of infection can be a serious risk to bee colonies, threatening its survival and indicating the importance of a regular and timely replacement of queens.

Attempts to breed Varroa-resistant bees are not yet successful. A 6 year survey of 150 honeybee colonies, with no acaricides applied and frees swarming, revealed that 3 years after the observation began the bee death in winter reached $80 \%$, but decreased to $12-18 \%$ over the next 2 years. Finally, only 11 bee colonies 
remained [108]. In France during 7 year monitoring of 82 bee colonies those treated with acaricides and not treated were compared. According to mortality during the winter the colonies did no differ significantly, but the bees from untreated colonies collected less nectar (by $41 \%$ ). Thus, in mite-resistant bees the honey production is lower that are not economically profitable [109].

Recently, the treatment of viral infections in bees using small interfering RNA (miRNA, siRNA) due to posttranscriptional silencing seems to be promising. Small interfering RNAs, binding to viral RNA, lead to virus degradation $[110,111]$. The viral RNA, when replicating with dsRNA formation, is a source of miRNA [112, 113]. Recently, the gene knockout was used against IBPV infection good effect with a decrease of percent of bet colony losses [114). It was found that viral dsRNA, when fed to bees, activates the degradation of IBPV RNA. However, such products are costly, and it is difficult to provide their targeted delivery to the organs and tissues of the insect. A similar approach was used for the relief of the DWV symptoms. In the bees fed with relevant dsRNA the DWV replication was repressed [115]. RNAases are another potentially effective agent to combat viral infections in bees. For example, RNase can inactivate ABPV when the virus suspension is pre-incubated in vitro. This suspension became harmless to larvae when inoculated [115]. However, a complicated problem of delivering these preparations to bee hemolymph still remains actual.

So, the most important of viruses found in honey bees are deformed wing virus (DWV), the acute paralysis virus (ABPV), chronic paralysis virus (CBPV), Kashmir virus (KBV), the sacbrood virus (SBV), and black queen cell virus (BQCV). ABPV, BQCV, CBPV, DWV are detected in pollen, BQCV and DWV can also be found in honey, and ABPV, CBPV, KBV and SBV are reported in beebread, honey, pollen and royal jelly. Correlation between high virus loads and Varroa destructor infestation indicates that the mite serves as agent predisposing bees to viral infection or activation of latent viruses. Under per or inoculation the viruses in most cases are not lethal for bees, whereas they lead to mass death in a short time when vectored by $V$. destructor. Bedides, to prevent the manifestation of bee parasitic mite syndrome, it is necessary to take into account local climate condition and used beekeeping rechnologies.

\section{REFEREN C ES}

1. Grobov O.F., B atuev Yu.M., Kuz'micheva N.V., S i chanok E.V. Pchelovodstvo, 2006, 7: 26-28 (in Russ.).

2. Runckel C., Flenniken M.L., Engel J.C., Ruby J.G., Ganem D., Andi n o R., D e Risi J.L. Temporal analysis of the honey bee microbiome reveals four novel viruses and seasonal prevalence of known viruses, Nosema, and Crithidia. PLoS ONE, 2011, 6: e20656 (doi: 10.1371/journal.pone.0020656).

3. B a il e y L., B a 11 B.V., W o ods R.D. An iridovirus from bees. J. Gen. Virol., 1976, 31: 459-461 (doi: 10.1099/0022-1317-31-3-459).

4. Bromenshenk J.J., Henderson C.B., Wick C.H., Stanford M.F., Zulich A.W., Jabbour R.E., Deshpande S.V., M c Cubbin P.E., S e c comb R.A., We lch P.M., Williams T., Firth D.R., Skow ronski E., Lehmann M.M., Bilimoria S.L., Gres s J., W a n n e r K.W., C r a m e r R.A., Jr. Iridovirus and microsporidian linked to honey bee colony decline. PLoS One, 2010, 5(10): e13181 (doe: 10.1371/journal.pone.0013181).

5. vanEngelsdorp D., Hayes J., Jr., U nde rwood R.M., P e t t is J. A survey of honey bee colony losses in the U.S., fall 2007 to spring 2008. PLOS ONE, 2008, 3(12): e4071 (doi: 10.1371/journal.pone.0004071).

6. van Engelsdorp D., Evans J.D., Sa egerman C., Mullin C., Haubruge E., Nguen B.K., Frazier M., Frazier J., Cox-Foster D., Chen Y., Underwood R.M., T a r p y D.R., P e t t is J.S. Colony sollapse visorder: a descriptive study. PloS ONE, 2009, 4(8): e6481 (doi: 10.1371/journal.pone.0006481).

7. vanEngelsdorp D., Speybroeck N., Evans J.D., Nguyen B.K., Mullin C., 
Frazier M., Frazier J., Cox-Foster D., Chen Y., Tarpy D.R., Haubruge E., P e t t is J.S., S a e g e r m a $n$ C. Weighing risk factors associated with bee colony collapse disorder by classification and regression tree analysis. J. Econ. Entomol., 2010, 103(5): 1517-1523 (doi: 10.1603/EC09429).

8. B a iley L., B all B.V., Perry J.N. The prevalence of viruses of honey bees in Britain. Ann. Appl. Biol., 1981, 97: 109-118 (doi: 10.1111/j.1744-7348.1981.tb02999.x).

9. B a k o n y i T., Farkas R., Szendrц i A., Dobos-Kovács M., Rusvai M. Detection of acute bee paralysis virus by RT-PCR in honey bee and Varroa destructor samples: rapid screening of representative Hungarian apiaries. Apidologie, 2002, 33: 29-40 (doi: 10.1051/apido:2001004).

10. Te nt cheva D., Ga thier L., Z a p pulla N., Dainat B., Cous serans F., C o li n M.E., B e rg o i n M. Prevalence and seasonal variations of six bee viruses in Apis mellifera L. and Varroa destructor mite populations in France. Appl. Environ. Microbiol., 2004, 70: 7185-7191 (doi: 10.1128/AEM.70.12.7185-7191.2004).

11. Chen Y.P., Pet t is J.S., F e ld la u fe $\mathrm{r}$ M.F. Detection of multiple viruses in queens of the honey bee, Apis mellifera L. J. Invertebr. Pathol., 2005, 90: 118-121 (doi: 10.1016/j.jip.2005.08.005).

12. A u be r t M. Impact of virus infection in honey bees. In: Virology and the honey bee /M. Aubert, B.V. Ball, I. Fries, R.F.A. Moritz, N. Milani, I. Bernardinelli (eds.). European Communities, Luxembourg, 2008: 233-253.

13. Grobov O.F., Guze eva L.N., Rodionova Z.E. Opasnye bolezni $i$ vrediteli pchel [Honeybee diseases and pests (in Russ.)]. Moscow, 1992.

14. P o lt o r z h i ts k y a R.S. Epizootologiya, immunobiologiya, farmakologiya, sanitariya, 2008, 1: 54-60 (in Russ.).

15. Ga rrido C. Reproduktionssteuerung bei der parasitischen Bienenmilbe Varroa destructor Anderson \& Trueman (ehemals Varroa jacobsoni). Ph.D. Thesis at the Faculty of Biology at the University of Hohenheim. Hohenheim, 2008.

16. R a th W. Co-adaptation of Apis cerana Fabr. and Varroa jacobsoni Oud. Apidologie, 1999, 30: 97-110 (doi: 10.1051/apido:19990202).

17. B o e c king O., S p ivak M. Behavioral defenses of honey bees against Varroa jacobsoni Oud. Apidologie, 1999, 30(2-3): 141-158 (doi: 10.1051/apido:19990205).

18. R a t h W. The key to Varroa - the drones of Apis cerana and their cell cap. Am. Bee J., 1992, 132(5): 329-331.

19. Y a n g X., C ox-Foste r D.L. Impact of an ectoparasite on the immunity and pathology of an invertebrate: evidence for host immune suppression and viral amplification. PNAS USA, 2005, 102: 7470-7475 (doi: 10.1073/pnas.0501860102).

20. Nazzi F., Brown S.P., Annoscia D., Del Piccolo F., Di Prisco G., Varricchio P., Vedova G.D., Cattonaro F., Caprio E., PennacchioF. Synergistic parasite-pathogen interactions mediated by host immunity can drive the collapse of honeybee colonies. PLOS/pathogens, 2012, 8(6): e1002735 (doi: 10.1371/journal.ppat.1002735).

21. Yue C., Genersch E. RT-PCR analysis of deformed wing virus in honeybees (Apis mellifera) and mites (Varroa destructor). J. Gen. Virol., 2005, 86: 3419-3424 (doi: 10.1099/vir.0.81401-0).

22. B ow e n-Walke r P.L., Marti n S.J., Gun n A. The transmission of deformed wing virus between honey bees (Apis mellifera L.) by the ecto-parasitic mite Varroa jacobsoni Oud. J. Invertebr. Pathol., 1999, 73: 101-106 (doi: 10.1006/jipa.1998.4807).

23. K h a n b e k ov a E.M., R u b t s o v a L.E. XIV Mezhunarodnaya konferentsiya «Biologicheskoe raznoobrazie Kavkaza i yuga Rossii», posvyashchennaya 70-letiyu G.M. Abdurakhmanova [Proc. XIV Int. Conf. «Biodiversity of the Caucasus and Southern Russia» (in Russ.)]. Makhachkala, 2012: 381-385.

24. Khanbe k ova E.M., Rubtsova L.E. Proc. Azerb. Sos. Zool., 2013, 5(1): 196-207.

25. Shim a nuki H., Cald e rone N.W., K n ox D.A. Parasitic mite syndrome: the symptoms. Am. Bee J., 1994, 134: 827-828.

26. Yang X., Cox-F o s t e r D. Effects of parasitization by Varroa destructor on survivor ship and physiological traits of Apis mellifera in correlation with viral incidence and microbial challenge. Parasitology, 2007, 134: 405-412 (doi: 10.1017/S0031182006000710).

27. Che n Y.P., S i e de R. Honey bee viruses. Adv. Virus Res., 2007, 70: 33-80 (doi: 10.1016/S00653527(07)70002-7).

28. Genersch E., Yue C., Fries I., de Miranda J.R. Detection of deformed wing virus, a honey bee viral pathogen, in bumble bees (Bombus terrestris and Bombus pascuorum) with wing deformities. J. Invertebr. Pathol., 2006, 91: 61-63 (doi: 10.1016/j.jip.2005.10.002).

29. Udina I.G., Kunizheva S.S., Zlobin V.I., Grishe chkin A.E., Kalashnik ov A.E., K rivts o v N.I., U c h a e va V.S. Voprosy virusologii, 2010, 55: 37-40 (in Russ.).

30. L u c h k o M.A., S ot n i k ov A.N. Veterinariya, 2012, 6: 9-14 (in Russ.).

31. Kha nbe kova E.M., Rubt s ova L.E., B ab i n Yu.Yu., E 1 a t k i n N.P., Lavrukhin D.K., T r e t'y a k o v A.V., S p r y g i n A.V. Porazhenie medonosnoi pchely Apis mellifera caucasica Gorb. virusami i parazitami i sostoyanie pchelinykh semei v raznykh ekologogeograficheskikh usloviyakh Bol'shogo Kavkaza [Viruses and parasites of Apis melifera caucasica 
Gorb. as related to losses of honeybee colonies in Big Caucasus mountings in Azerbaijan under different ebvironmental conditions and location]. Sel'skokhozyaistvennaya Biologiya [Agricultural Biology], 2013, 6: 43-54 (doi: 10.15389/agrobiology.2013.6.43rus in Russ.; 10.15389/agrobiology.2013.6.43eng in Eng.).

32. Fujiyuki T., Take uchi H., Ono M., O hka S., S a saki T., Nomoto A., $\mathrm{K} \mathrm{u} \mathrm{b} \mathrm{o} \mathrm{T.} \mathrm{Novel} \mathrm{insect} \mathrm{picornalike} \mathrm{virus} \mathrm{identified} \mathrm{in} \mathrm{the} \mathrm{brains} \mathrm{of} \mathrm{aggressive} \mathrm{worker} \mathrm{honey-}$ bees. J. Virol., 2004, 78: 1093-1100 (doi: 10.1128/JVI.78.3.1093-1100.2004).

33. Rortais A., Tentcheva D., Papachristoforou A., Gauthier L., Ar n o ld G., C o l i n M.E., B e r g o i n M. Deformed wing virus is not related to honey bees' aggressiveness. Virol. J., 2004, 3: e61 (doi: 10.1186/1743-422X-3-61).

34. W i 11 i a m s G.R., R o g e r s R.E.L., K a $1 \mathrm{ks}$ t e i n A.L., T a y lo r B.A., $\mathrm{S}$ h u t 1 e $\mathrm{r}$ D., O stig u y N. Deformed wing virus in western honey bees (Apis mellifera) from Atlantic Canada and the first description of an overtly infected emerging queen. J. Invertebr. Pathol., 2009, 101: 77-79 (doi: 10.1016/j.jip.2009.01.004).

35. A 11 e n M.F., B a 11 B.V. The incidence and world distribution of honey bee viruses. Bee World, 1996, 77: 141-162 (doi: 10.1080/0005772X.1996.11099306).

36. E 11 is J.D., M u n n P.A. The worldwide health status of honey bees. Bee World, 2005, 86: 88-101 (doi: 10.1080/0005772X.2005.11417323).

37. Nordström S., Fries I., A a rhus A., Hansen H., Ko r pela S. Virus infections in Nordic honey bee colonies with no, low or severe Varroa jacobsoni infestations. Apidologie, 1999, 30(6): 475-484 (doi: 10.1051/apido:19990602).

38. N o rdst rö m S. Virus infections and Varroa mite infestations in honey bee colonies. Ph.D. Thesis, Swedish University of Agricultural Sciences. Uppsala, 2000.

39. S a ntillán-G a 1 i c i a M.T., C a r z a n ig a R., B a 11 B.V., A 1 d e r s o n P.G. Immunolocalization of deformed wing virus particles within the mite Varroa destructor. J. Gen. Virol., 2008, 89: 1685-1689 (doi: 10.1099/vir.0.83223-0).

40. D a i n a t B., K e n T., B e r t h o u d H., N e u m a n n P. The ectoparasitic mite Tropilaelaps mercedesae (Acari, Laelapidae) as a vector of honeybee viruses. Insectes Soc., 2009, 56: 40-43 (doi: 10.1007/s00040-008-1030-5).

41. Forsgren E., d e Mirand a J.R., I s a ks s o n M., W e i S., Frie s I. Deformed wing virus associated with Tropilaelaps mercedesae infesting European honey bees (Apis mellifera). Exp. Appl. Acarol., 2009, 47: 87-97 (doi: 10.1007/s10493-008-9204-4).

42. S h e n M., Cu i L., O st ig u y N., C ox-F o s t e r D. Intricate transmission routes and interaction between picorna-like viruses (Kashmir bee virus and sac brood-virus) with the honey bee host and the parasitic Varroa mite. J. Gen. Virol., 2005, 86: 2281-2289 (doi: 10.1099/vir.0.80824-0).

43. G i s d e r S., A u m e i e r P., G e n e r s c h E. Deformed wing virus (DWV): viral load and replication in mites (Varroa destructor). J. Gen. Virol., 2009, 90: 463-467 (doi: 10.1099/vir.0.005579-0).

44. E y e r M., C h e n Y.P., S c h ä f e r M.O., P e t t i s J., N e u m a n n P. Small hive beetle, Aethina tumida, as a potential biological vector of honey bee viruses. Apidologie, 2009, 40: 419-428 (doi: 10.1051/apido:2008051).

45. Yu e C., S chröder M., Gisder S., Ge ners ch E. Vertical transmission routes for deformed wing virus of honeybees (Apis mellifera). J. Gen. Virol., 2007, 88: 2329-2336 (doi: 10.1099/vir.0.83101-0).

46. H a ils R.S., B a 11 B.V., G e ne rs ch E. Infection strategies of insect viruses. In: Virology and the honey bee /M. Aubert, B.V. Ball, I. Fries, R.F.A. Moritz, N. Milani, I. Bernardinelli (eds.). European Communities, Luxembourg, 2008: 255-275.

47. De Miranda J., Genersch E. Deformed wing virus. J. Invertebr. Pathol., 2010, 103: 48-61 (doi: 10.1016/j.jip.2009.06.012).

48. De Miranda J.R., Fries I. Venereal and vertical transmission of deformed wing virus in honeybees (Apis mellifera L.). J. Invertebr. Pathol., 2008, 98: 184-189 (doi: 10.1016/j.jip.2008.02.004).

49. Hung A.C.F., Ad a m s J.R., Sh i m a n u k H. Bee parasitic mite syndrome: II. The role of Varroa mite and viruses. Am. Bee J., 1995, 135: 702.

50. S u m pte r D.J.T., M a rti n S.J. The dynamics of virus epidemics in Varroa-infested honey bee colonies. J. Anim. Ecol., 2004, 73: 51-63 (doi: 10.1111/j.1365-2656.2004.00776.x).

51. Shen M., Yang X., Cox-Foster D., Cui L. The role of Varroa mites in infections of Kashmir bee virus (KBV) and deformed wing virus (DWV) in honeybees. Virology, 2005, 342: 141-149 (doi: 10.1016/j.virol.2005.07.012).

52. B erenyi O., Bakonyi T., Derakhshifar I., Köglberger H., Nowotny N. Occurrence of six honeybee viruses in diseased Austrian apiaries. Appl. Environ. Microbiol., 2006, 72: 2414-2420 (doi: 10.1128/AEM.72.4.2414-2420.2006).

53. Highfield A.C., El- Nagar A., M a c Kinde r L.C.M., Noel L.M.L.J., H a 11 M.J., M a r t i n S.J., S c h r o e d e r D.C. Deformed wing virus implicated in overwintering honeybee colony losses. Appl. Environ. Microbiol., 2009, 75: 7212-7220 (doi: 10.1128/AEM.02227-09).

54. Guzmán-Novoa E., Eccles L., Calvete Y., Mcgowan J., Kelly P.G., Correa-B e níte z A. Varroa destructor is the main culprit for the death and reduced popula- 
tions of overwintered honey bee (Apis mellifera) colonies in Ontario, Canada. Apidologie, 2010, 41: 443-450 (doi: 10.1051/apido/2009076).

55. D a in at B., Evans J.D., Chen Y.P., Gauthi e r L., N e u mann P. Predictive markers of honey bee colony collapse. PLOS ONE, 2012, 7(2): e32151 (doi: 10.1371/journal.pone.0032151).

56. Chantawannakul P., Ward L., B o o nham N., B rown M. A scientific note on the detection of honeybee viruses using real-time PCR (TaqMan) in Varroa mites collected from a Thai honeybee (Apis mellifera) apiary. J. Invertebr. Pathol., 2006, 91: 69-73 (doi: 10.1016/j.jip.2005.11.001).

57. To polska G., B a 11 B.V., A 11 e n M. Identification of viruses in bees from two Warsaw apiaries. Medycyna Weterynaryina, 1995, 51: 145-147.

58. Genersch E., von der Ohe W., Katz H., Schroeder A., Otten C., B üchle r R., B e rg S., Ritter W., M ühlen W., G is d e r S., M e ixner M., Li e big G., Rosenkranz P. The German bee monitoring project: a long term study to understand periodically high winter losses of honey bee colonies. Apidologie, 2010, 41(3): 332-352 (doi: 10.1051/apido/2010014).

59. va $\mathrm{Eng}$ e $\mathrm{ls}$ d o r p D., M e ix n e r M. A historical review of managed honey bee populations in Europe and the United States and the factors that may affect them. J. Invertebr: Pathol., 2010, 3(Suppl. 1): S80- S95 (doi: 10.1016/j.jip.2009.06.011).

60. Zhang X., H e S.Y., Evans J.D., P e t t i s J.S., Y in G.F., Che n Y.P. New evidence that deformed wing virus and black queen cell virus are multi-host pathogens. J. Invertebr. Pathol., 2012, 109(1): 156-159 (doi: 10.1016/j.jip.2011.09.010).

61. Gauthier L., Ravallec M., Tournaire M., Cousserans F., Bergoin M., $\mathrm{D}$ a i nat B., d e $\mathrm{M}$ i r a nd a J.R. Viruses associated with ovarian degeneration in Apis mellifera L. queens. PLOS ONE, 2011, 6(1): e16217 (doi: 10.1371/journal.pone.0016217).

62. C h e n Y.P., P e t t i s J.S., C o 11 i n s A., F e $1 \mathrm{~d} 1$ a u f e r M.F. Prevalence and transmission of honey bee viruses. Appl. Environ. Microbiol., 2006, 72: 606-611 (doi: 10.1128/AEM.72.1.606611.2006).

63. Ch e n Y.P., Eva n s J.D., F e $1 \mathrm{~d} 1 \mathrm{a} \mathrm{u}$ fe $\mathrm{r}$ M.F. Horizontal and vertical transmission of viruses in the honey bee, Apis mellifera. J. Invertebr. Pathol., 2006, 92: 152-159 (doi: 10.1016/j.jip.2006.03.010).

64. Chen Y.P., P e t t i s J.S., C o 11 i n s A., F e $1 \mathrm{~d} \mathrm{l}$ a u f e r M.F. Prevalence and transmission of honey bee viruses. Appl. Environ. Microbiol., 2006, 72: 606-611 (doi: 10.1128/AEM.72.1.606611.2006).

65. H u $\mathrm{ng}$ A.C.F. PCR detection of Kashmir bee virus in honey bee excreta. J. Apic. Res., 2000, 39: 103-106.

66. O ngus J.R., P e te rs D., B o n mat i n J.-M., B e ng s ch E., V lak J.M., va $n$ $\mathrm{O}$ e r s M.M. Complete sequence of a picorna-like virus of the genus Iflavirus replicating in the mite Varroa destructor. J. Gen. Virol., 2004, 85: 3747-3755 (doi: 10.1099/vir.0.80470-0).

67. Z h a ng Q.S., O ngus J.R., B o ot W.J., C a $11 \mathrm{~s} \mathrm{J.,} \mathrm{Bonmatin} \mathrm{J.M.,} \mathrm{B} \mathrm{e} \mathrm{ng} \mathrm{s} \mathrm{c} \mathrm{h} \mathrm{E.,}$ P e t e r s D. Detection and localization of picorna-like virus particles in tissues of Varroa destructor, an ectoparasitic of the honey bee, Apis mellifera. J. Invertebr. Pathol., 2007, 96: 97105 (doi: 10.1016/j.jip.2007.03.019).

68. M o ore J., J i ronkin A., Chand le r D., B u r roughs N., Evans D.J., Ry a b o v E.V. Recombinants between Deformed wing virus and Varroa destructor virus-1 may prevail in Varroa destructor-infested honeybee colonies. J. Gen. Virol., 2011, 92: 156-161 (doi: 10.1099/vir.0.025965-0).

69. $\mathrm{M}$ a у о M.A. Names of viruses and virus species - an editorial note. Arch. Virol., 2002, 147: 1463-1464 (doi: 10.1007/s007050200042).

70. $\mathrm{M}$ a y о M.A. A summary of taxonomic changes recently approved by ICTV. Arch. Virol., 2002, 147: 1655-1663 (doi: 10.1007/s007050200039).

71. F a u c o n J.-P. Paralysie chronique ou maladie noire. In: Précis de pathologie: connaître et traiter les maladies et abeilles. CNEVA-FNOSAD, 1992: 204-212.

72. H u n g A.C., S h i m a n u k i H., K n o x D.A. In-apparent infection of acute paralysis virus and Kashmir bee virus in the U.S. honey bees. Am. Bee J., 1996, 136: 874-876.

73. B a t u e v Yu.M. Pchelovodstvo, 1979, 7: 10-11 (in Russ.).

74. $\mathrm{N}$ i e $1 \mathrm{~s}$ e $\mathrm{n}$ S.L., $\mathrm{N}$ i c o $\mathrm{la}$ i s e $\mathrm{n} \mathrm{M.,} \mathrm{K} \mathrm{r} \mathrm{y} \mathrm{g} \mathrm{e} \mathrm{r}$ P. Incidence of acute bee paralysis virus, black queen cell virus, chronic bee paralysis virus, deformed wing virus, Kashmir bee virus and sac-brood virus in honey bees (Apis mellifera) in Denmark. Apidologie, 2008, 39: 310-314 (doi: 10.1051/apido:2008007).

75. S i e d e R., K ön ig M., B ü chle r R., Failing K., Thi e l H.J. A real-time PCR based survey on acute bee paralysis virus in German bee colonies. Apologia, 2008, 39: 650-661 (doi: 10.1051/apido:2008044).

76. B a i 1 e y L., C a r p e $n$ t e r J.M., W o o d s R.D. Egypt bee virus and Australian isolates of Kashmir bee virus. J. Gen. Virol., 1979, 43: 641-647 (doi: 10.1099/0022-1317-43-3-641).

77. B a i 1 e y L., W o o d s R.D. Two more small RNA viruses from honey bees and further observations on sac-brood and acute bee-paralysis viruses. J. Gen. Virol., 1977, 37: 175-182. 
78. R i b i è re M., B a 11 B.V., A u b e rt M. Natural history and geographic distribution of honey bee viruses. In: Virology and the honey bee. M. Aubert, B.V. Ball, I. Fries, R.F.A. Moritz, N. Milani, I. Bernardinelli (eds.). European Communities, Luxembourg, 2008: 15-84.

79. A n d e r s o n D.L. Viruses of New Zealand honey bees. New Zealand Beekeeper, 1985, 188: 8-10.

80. A nde rs o n D.L. Pests and pathogens of the honeybee (Apis mellifera L.) in Fiji. J. Apic. Res., 1990, 29: 53-59.

81. S i e d e R., D e rakhshifar I., O t t e n C., B e renyi O., B a konyi T., Kog $\mathrm{l}$ b e rge r H., B ü c h le r R. Prevalence of Kashmir bee virus in Central Europe. J. Apic. Res., 2005, 44: 129 (doi: 10.1080/00218839.2005.11101164).

82. H u ng A.C., P e $\mathrm{ng}$ C.Y.S., $\mathrm{S}$ h i m a n u k i H. Nucleotide sequence variation in Kashmir bee virus isolated from Apis mellifera L. and Varroa jacobsoni Oud. Apidologie, 2000, 31: 17-23 (doi: 10.1051/apido:2000101).

83. To d d J., d e M i r a n d a J., B a 11 B.V. Incidence and molecular characterization of viruses found in dying New Zealand honey bee (Apis mellifera) colonies infested with Varroa destructor: Apidologie, 2007, 38: 354-367 (doi: 10.1051/apido:2007021).

84. S i e d e R., B ü c h l e r R. First detection of Kashmir bee virus in Hesse, Germany. Berl. Münch. Tierärztl. Wochenschr., 2004, 117(1-2): 12-15.

85. M a or i E., Lavi S., Moze s-Ko ch R., Gant man Y., E d e lbau m O., T a n $n$ e E., S e l a I. Isolation and characterization of IAPV, a dicistrovirus affecting honeybees in Israel: evidence for intro- and inter-species recombination. J. Gen. Virol., 2007, 88: 3428-3438 (doi: 10.1099/vir.0.83284-0).

86. $\mathrm{C}$ h e $\mathrm{n}$ Y.P., E v a n s J.D. Historical presence of Israeli acute paralysis virus in the United States. Am. Bee J., 2007, 147: 1027-1028.

87. Cox-Foster D.L., Conlan S., Holmes E.C., Palacios G., Evans J.D., Moran N.A., Quan P.L., B ries e T., Hornig M., G e is e r D.M., M a r t inson V., va n Enge ls dorp D., Kalkste in A.L., D rysdale A., H u J., Zh a i J., Cui L., Hutch is on S.K., S i mons J.F., Eghol m M., P e t t is J.S., $\mathrm{L}$ i p k i n W.I. A metagenomic survey of microbes in honey bee colony collapse disorder. Science, 2007, 318(5848): 283-287 (doi: 10.1126/science.1146498).

88. Pala cios G., H u i J., Quan P.L., Kalkste in A., Honkavuori K.S., B u s se t t i A.V., C on lan S., Evans J., Chen Y.P., vanEngelsdoorp D., Efrat H., $\mathrm{P}$ e t t is J., Cox-Foster D., Holmes E.C., B ri e s e T., Li p k i n W.I. Genetic analysis of Israel Acute Paralysis Virus. Distinct clusters are circulating in the United States. J. Virol., 2008, 82(13): 6209-6217 (doi: 10.1128/JVI.00251-08).

89. B l a n c hard P., S churr F., Celle O., Cougoule N., Drajnude l P., $\mathrm{T}$ h i e $\mathrm{r}$ y R., F a u c o n J.P., R i b i è $\mathrm{r}$ e M. First detection of Israeli acute paralysis virus (IAPV) in France, a dicistrovirus affecting honeybees (Apis mellifera). J. Invertebr. Pathol., 2008, 99: 348-350 (doi: 10.1016/j.jip.2008.07.006).

90. De Miranda J.R., Drebot M., Tylor S., Shen M., C a meron C.E., S tolz D.B., $\mathrm{C}$ a $\mathrm{m}$ a $\mathrm{z}$ i n e S.M. Complete nucleotide sequence of Kashmir bee virus and comparison with acute bee paralysis virus. J. Gen. Virol., 2004, 85: 2263-2270 (doi: 10.1099/vir.0.79990-0).

91. Dall D.J. Multiplication of Kashmir bee virus in pupae of the honey bee, Apis mellifera. J. Invertebr. Pathol., 1987, 49: 279-290 (doi: 10.1016/0022-2011(87)90060-7).

92. Brodsgard G., Ritter J.W., Hansen H., Brodsgaard H.F. Interactions among Varroa jacobsoni mites, acute bee paralysis virus, and Paenibacillus larvae and their influence on mortality of larval honey bees in vitro. Apidologie, 2000, 31: 543-554 (doi: 10.1051/apido:2000145).

93. Chen Y.P., Pettis J.S., Evans J., Kramer M., Feldlaufer M.F. Transmission of Kashmir bee virus by the ectoparasitic mite Varroa destructor: Apidologie, 2004, 35: 441-448 (doi: 10.1051/apido:2004031).

94. Chen Y.P., Higgins J.A., Feldlaufer M.F. Quantitative analysis of deformed wing virus infection in the honey bee, Apis mellifera L. by real-time RT-PCR. Appl. Environ. Microbiol., 2004, 71: 436-441 (doi: 10.1128/AEM.71.1.436-441.2005).

95. O 1 d royd B.P. What's killing American honey bees? PLoS Biol., 2007, 5: e168 (doi 10.1371/journal.pbio.0050168).

96. J o hns o n R.M., Evans J.D., R ob in son G.E., B e re n b a u M.R. Changes in transcript abundance relating to colony collapse disorder in honey bees (Apis mellifera). PNAS USA, 2009, 106: 14790-14795 (doi: 10.1073/pnas.0906970106).

97. D e Miranda J., Cordoni G., B udge G. The acute bee paralysis virus-Kashmir bee virus-Israeli acute paralysis virus complex. J. Invertebr. Pathol., 2010, 103: 30-47 (doi: 10.1016/j.jip.2009.06.014).

98. A u b e r t M. Impact of virus infection in honey bees. In: Virology and the honey bee /M. Aubert, B.V. Ball, I. Fries, R.F.A. Moritz, N. Milani, I. Bernardinelli (eds.). European Communities, Luxembourg, 2008: 233-253.

99. P ot t s S., B i e s me ij e r J., Kre me n C., $\mathrm{N}$ e u ma n n P., S c hweige r O., K u $\mathrm{n}$ i n W.E. Global pollinator declines: trends, impacts and drivers. Trends Ecol. Evol., 2010, 25(6): 345-353 (doi: 10.1016/j.tree.2010.01.007).

100. Celle O., Blanchard P., Olivier V., S c hurr F., Cougoule N., Faucon J.P., $\mathrm{R}$ i b i è r e $\mathrm{M}$. Detection of Chronic bee paralysis virus (CBPV) genome and its replicative 
RNA form in various hosts and possible ways of spread. Virus Res., 2008, 133(2): 280-284 (doi: 10.1016/j.virusres.2007.12.011).

101. Sotnikov A.N., Korolev A.V. Pchelovodstvo, 2014, 5: 30-32 (in Russ.).

102. Invernizzi C., Rivas F., Bettucci L. Resistance to chalk brood disease in Apis mellifera L. (Hymenoptera: Apidae) colonies with different hygienic behavior. Neotropical Entomology, 2011, 40: 28-34 (doi: 10.1590/S1519-566X2011000100004).

103. Martin S.J. The role of Varroa and viral pathogens in the collapse of honeybee colonies: a modeling approach. J. Appl. Ecol., 2001, 38: 1082-1093.

104. Fries I., Camazine S., S neyd J. Population dynamics of Varroa jacobsoni: a model and a review. Bee World, 1994, 75: 5-28.

105. Genersh E. Honey bee pathology: current threats to honey bees and beekeeping. Appl. Microbiol. Biotechnol., 2010, 87(1): 87-97 (doi: 10.1007/s00253-010-2573-8).

106. Yue C., Schröder M., Bienefeld K., Genersch E. Detection of viral sequences in semen of honeybees (Apis mellifera): evidence for vertical transmission of viruses through drones. J. Invertebr. Pathol., 2006, 92: 93-96 (doi: 10.1016/j.jip.2006.03.001).

107. Fries I., Imdorf A., Rosenkranz P. Survival of mite infested (Varroa destructor) honey bee (Apis mellifera) colonies in a Nordic climate. Apologia, 2006, 37: 564-570 (doi: 10.1051/apido:2006031).

108. Le Conte Y., de Vaublanc G., Crauser D., Jeanne F., Rousselle J.C., Bécard J.M. Honey bee colonies that have survived Varroa destructor. Apidologie, 2007, 38: 566-572 (doi: 10.1051/apido:2007040).

109. Meister G., Tuschl T. Mechanisms of gene silencing by double-stranded RNA. Nature, 2004, 431: 343-349 (doi: 10.1038/nature02873).

110. Mello C.C., Conte D., Jr. Revealing the world of RNA interference. Nature, 2004, 431: 338-342 (doi: 10.1038/nature02872).

111. Vo in net O. Induction and suppression of RNA silencing: insights from viral infections. Nat. Rev., 2005, 6(3): 206-220 (doi: 10.1038/nrg1555).

112. Obbard D.J., Gordon K.H.J., Buck A.H., Jiggins F.M. The evolution of RNAi as a defense against viruses and transportable elements. Philos. Trans. R. Soc. Lond., B, Biol. Sci., 2009, 364: 99-115 (doi: 10.1098/rstb.2008.0168).

113. Hunter W., Ellis J., vanEngelsdorp D., Hayes J., Westervelt D., Glick E., Williams M., Sela I., Maori E., Pettis J., Cox-Foster D., Paldi N. Large-scale field application of RNA interference (RNAi) technology to reduce impact of Israeli Acute Paralysis Virus (IAPV) induced disease in honey bees (Apis mellifera), Hymenoptera: Apidae. PLoS/pathogens, 2010, 6(12): e1001160 (doi: 10.1371/journal.ppat.1001160).

114. Desai S.D., Eu Y.J., Whyard S., Currie R.W. Reduction in deformed wing virus infection in larval and adult honey bees (Apis mellifera L.) by double-stranded RNA ingestion. Insect. Mol. Biol., 2012, 21(4): 446-455 (doi: 10.1111/j.1365-2583.2012.01150.x).

115. Fedorova A.A., Azzami K., Ryabchikova E.I., Spitsyna Y.E., Silnikov V.N., Ritter W., Gross H.J., Tautz J., Vlassov V.V., Beier H., Zenkova M.A. Inactivation of a non-enveloped RNA virus by artificial ribonucleases: honey bees and acute bee paralysis virus as a new experimental model for in vivo antiviral activity assessment. Antiviral Res. 2011, 91(3): 267-277 (doi: 10.1016/j.antiviral.2011.06.011). 